\title{
ANALISIS PENGELOLAAN PIUTANG DAN KERUGIAN PIUTANG TAK TERTAGIH PADA PT. BANK RAKYAT INDONESIA CABANG
}

\author{
Ryfan Racel Rompas ${ }^{1}$, Inggriani Elim ${ }^{2}$, I Gede Suwetja ${ }^{3}$ \\ 1,2,3 Jurusan Akuntansi, Fakultas Ekonomi dan Bisnis, Universitas Sam Ratulangi, Jl. Kampus Bahu, Manado, \\ 95115, Indonesia \\ E-mail : ryfanrompas@gmail.com
}

\begin{abstract}
The provision of credit facilities by PT. Bank Rakyat Indonesia branch Bitung will generate accounts receivable. The more the provision of services on credit, the greater the risk for uncollectible. The purpose of this study is to analyze the management of receivables and losses on bad debts at PT. Bank Rakyat Indonesia Branch Bitung. This research using descriptive method analyze that is analyzing data by determining, collecting, clarifying, and interpreting resulting in a clear picture of the control of accounts receivable against the risk of bad debts. To obtain the necessary data, the researcher use observation and interview techniques method. The type of data is primary data and secondary data. The classification of receivables applied to PT, Bank Rakyat Indonesia Branch Bitung is in accordance with Financial Accounting Standard (FAS) No. 9. The policy of PT. Bank Rakyat Indonesia Branch Bitung in controlling the receivables is by estimate the accounts receivable at $3 \%$. If the bad debts are $<3 \%$, then the control of the accounts receivable is good. But if the bad debts are > 3\%, then the control of the account receivables is not good. From the controlling method of the account receivables, it can be see that the amount of bad debts at PT. Bank Rakyat Indonesia Branch Bitung is still $<3 \%$, so it can be concluded that the control of account receivables at PT. Bank Rakyat Indonesia Branch Bitung has been running well.

Keywords: Account Receivable and Bad Debt
\end{abstract}

\section{PENDAHULUAN}

Perusahaan merupakan badan usaha yang menjalankan kegiatan di bidang perekonomian (keuangan, industri, dan perdagangan), yang dilakukan secara terus menerus atau teratur dengan tujuan memperoeh keuntungan/laba. Dengan adanya laba yang cukup baik, maka suatu perusahaan akan mempunyai kredibiitas yang tinggi dan akan terus tumbuh dan bisa meningkatkan kredibilitas dalam persaingan bisnis.

Salah satu perusahaan yang sangat berperan penting dalam dunia usaha saat ini adalah perusahaan perbankan. Penawaran yang diberikan oleh perusahaan perbankan sendiri biasanya dilakukan dengan cara menyediakan fasilitas kredit. Penyediaan fasilitas kredit akan menguntungkan perusahaan karena menarik bagi calon debitur sehingga dapat meningkatkan pendapatan perusahaan. Di lain pihak bisa mendatangkan kerugian apabila debitur tidak dapat melaksanakan kewajibannya.

Pemberian kredit proses yang melibatkan dua pihak yaitu pihak pihak yang menerima kredit dan pemberi kredit, hutang bagi pihak debitur dan dimana akan timbul piutang bagi pihak kreditur. Akibat dari pemberian kredit akan menimbulkan hak penagihan piutang. Proses penagihan atas piutang sering diperhadapkan dengan resiko ketidaktertagihan dan kadang ketidaktertagihan tersebut tidak dapat

terhindarkan, yang membuat perusahaan dapat menanggung beban ketidaktertagihan atau disebut beban kerugian piutang (bad debt expense/ uncollectible account expense/ doubtful accounts expense). Beban kerugian piutang ini sangat mempengaruhi laba perusahaan karena tidak mengurangi jumlah laba perusahaan. Piutang yang tidak tertagih ini memerlukan perhatian khusus dari perusahaan agar dapat dikelola dengan baik. 
PT. Bank Rakyat Indonesia Cabang Bitung merupakan suatu lembaga keuangan yang memberikan pelayanan kepada masyarakat yang ingin menggunakan jasa perbankan. Kegiatan usaha pada PT. Bank Rakyat Indonesia Cabang Bitung lebih diarahkan kepada untuk melakukan usaha simpan pinjam dan penyaluran dananya dalam bentuk kredit. Penyediaan fasilitas secara kredit yang dilakukan oleh PT. Bank Rakyat Indonesia Cabang Bitung ini akan menimbulkan piutang. Semakin banyak penyediaan jasa secara kredit, maka semakin meningkat pula resiko untuk tidak tertagih.

\section{TINJAUAN PUSTAKA}

\subsection{Akuntansi}

Menurut American Accounting Association pengertian akuntansi adalah suatu proses mengukur, mengidentifikasi, dan melaporkan informasi ekonomi untuk memungkinkan adanya penilaian dan keputusan yang jelas dan tegas bagi mereka yang menggunakan informasi tersebut. Tuanakotta (2015:25), dalam buku teori audit kotemporer menyatakan akuntansi adalah proses mengidentifikasi, mengukur dan menyampaikan informasi ekonomi bagi para penggunanya dalam mempertimbangkan berbagai alternatif yang ada dan membuat kesimpulan. Akuntansi keuangan sebagai suatu proses yang berujung pada penyajian laporan keuangan untuk pengambilan keputusan oleh pihak internal maupun eksternal perusahaan yang meliputi investor sekarang dan investor potensial, karyawan, pemberi pinjaman, pemasok dan kreditur usaha lainnya, pelanggan, pemerintah, serta lembaga-lembaganya, dan masyarakat. Mulyadi (2016:66) dalam buku teori akuntansi menyatakan akuntansi keuangan digunakan untuk menyiapkan informasi akuntansi untuk orang diluar organisasi atau tidak terlibat dalam kegiatan sehari-hari dalam menjalankan perusahaan (pihak ekstern). Akuntansi keuangan sebuah proses pencatatan transaksi dan pelaporan hasil pencatatan kepada pihakpihak perusahaan. Bidang akuntansi yang menyediakan informasi akuntansi secara umum bagi para pemakai atau pengambil keputusan yang ada diluar organisasi.

\subsection{Akuntansi Keuangan (Financial Accounting)}

Menurut menurut Reeve, Warren, Duchac (2015:448-449) dalam buku pengantar akuntansi menyatakan akuntansi keuangan merupakan cabang akuntansi yang menekankan pada pencatatan transaksi menggunakan prinsip akuntansi berterima umum untuk perusahaan atau unit ekonomi lainnnya dan dengan pembuatan berbagai laporan secara periodik dari catatan tersebut. Akuntansi keuangan sebuah proses pencatatan transaksi dan pelaporan hasil pencatatan kepada pihak-pihak perusahaan. Bidang akuntansi yang menyediakan informasi akuntansi secara umum bagi para pemakai atau pengambil keputusan yang ada diluar organisasi.

\subsection{Pengendalian Internal}

Pengendalian intern adalah meliputi struktur organisasi dan segala cara serta tindakan dalam suatu perusahaan yang saling terkoordinasi dengan tujuan mengamankan harta kekayaan perusahaan, menguji ketelitian dan kebenaran data akuntansi, meningkatkan efisiensi operasi serta mendorong ketaatan terhadap kebijakan-kebijakan yang telah digariskan oleh pimpinan perusahaan (Mulyadi 2016:110).

\subsection{Manfaat Pengendalian}

Menurut Mulyadi (2016:110-115), dalam buku Sistem Akuntansi menyatakan, pengendalian dibutuhkan untuk mengurangi eksposur (ancaman) terhadap resiko. Oleh sebab itu, pengendalian yang efektif untuk mengurangi eksposur mencakup hal-hal berikut ini:

1. Pemisahan Tugas.

2. Kebijakan dan Prosedur.

\subsubsection{Pengendalian Internal Piutang Menurut COSO}

COSO (Committee Of Sponsoring Organization) adalah suatu komite yang di organisir oleh lima organisasi profesi yaitu IIA, AICPA, IMA, FEI, dan AAA pada bulan 
Oktober 1987. COSO memandang pengendalian intern merupakan rangkaian tindakan yang menembus seluruh organisasi. Model COSO adalah salah satu model pengendalian internal yang banyak digunakan oleh banyak auditor sebagai dasar untuk mengevaluasi dan mengembangkan pengendalian intern.

Menurut Sunyoto (2007:267) bahwa terdapat lima komponen pengendalian intern, yaitu:

1. Lingkungan Pengendalian

2. Penentuan Risiko

3. Aktivitas Pengendalian

4. Informasi dan Komunikasi

5. Pengawasan dan Pemantauan

\subsection{Konsep Kredit}

Undang-undang Perbankan Nomor 10 Tahun 1998 (Kasmir, 2015:115) mengungkapkan bahwa kredit adalah penyediaan uang atau tagihan yang dapat dipersembahkan dengan itu, berdasarkan persetujuan atau kesepakatan pinjaman meminjam antara bank dengan pihak lain yang mewajibkan pihak pijaman melunasi utangnya setelah jangka waktu dengan pemberian bunga. Kredit atau pembiayaan dapat berupa uang atau tagihan yang nilainya diukur dengan uang, kemudian adanya kesepakatan antara bank (kreditor) dengan nasabah penerima kredit (debitor), bahwa mereka sepakat sesuai perjanjian yang telah dibuatnya (Kasmir, 2015:115). Dapat disimpukan bahwa kredit adalah kesepakatan pinjaman miminjan antara kedua belah pihak, berupa uang atau tagihan yang nilainya diukur dengan nilai uang.

\subsubsection{Prosedur Pemberian Kredit}

Menurut Kasmir (2015:115-117) prosedur pemberian kredit secara umum dapat dibedakan antara pinjaman perseorangan dengan pinjaman oleh suatu badan hukum, kemudian dapat pula ditinjau dari segi tujuannya apakah konsumtif atau produktif. berikut :

Secara umum akan dijelaskan prosedur pembelian kredit oleh badan hukum sebagai

1. Pengajuan berkas-berkas

2. Penyelidikan Berkas Pinjaman

3. Wawancara

4. On The Spot

5. Wawancara II

6. Keputusan Kredit

7. Penandatanganan Akad Kredit atau Perjanjian Lainnya

8. Realisasi Kredit

9. Penyaluran atau Penarikan Dana

\subsection{Jenis-Jenis Kredit Bank Rakyat Indonesia (BRI)}

Menurut Kasmir (2015:34), ada 5 jenis kredit yang ditawarkan oleh Bank Rakyat Indonesia (BRI), yaitu:

1. Pinjaman Mikro

2. Pinjaman Ritel

3. Pinjaman Menengah

4. Pinjaman Program

\subsection{Alur Permohonan Kredit dari PT. Bank Rakyat Indonesia:}

Menurut Ahmed (2015:67), alur Permohonan Kredit dari PT. Bank Rakyat Indonesia sebagai berikut:

1. Nasabah menyerahkan berkas kepada bagian admin kredit.

2. Kelengkapan berkas (Identitas calon nasabah, ijin usaha, dokumen agunan).

3. Bagian admin kredit mencari data informasi calon nasabah dari BI 
4. Diserahkan kepada account officer (pemrakarsa) untuk memeriksa dan menganalisis kelayakan usaha.

5. Account Officer menyerahkan kepada kredit investigator/appraisal untuk memeriksa dan menilai agunan.

6. Setelah kredit investigator selesai menilai agunan dan account offocer (AO) selesai menganalisa kelayakan usaha maka paket kredit di ajukan ke pimpinan cabang untuk menyetujui paket kredit.

\subsection{Piutang}

Menurut Kasmir (2015:115) piutang menunjukkan adanya klaim perusahaan kepada pihak (perusahaan) lain akibat kejadian di waktu sebelumnya dalam bentuk uang, barang, jasa atau dalam bentuk aktiva non kas lainnya yang harus dilakukan penagih (collect) pada tanggal jatuh temponya.

\subsection{Piutang Menurut Standar Akuntansi Keuangan (PSAK No.9)}

Ada dua kategori penggolongan piutan menurut Standar Akuntansi Keuangan (PSAK No. 9), yaitu piutang usaha dan piutang lain-lain. Piutang terdiri atas tiga golongan yaitu piutang dagang (usaha), piutang bukan dagang, dan piutang penghasilan. Piutang dagang merupakan adanya janji lisan dari pembeli untuk membayar barang atau jasa yang dijual yang penagihannya tidak lebih dari satu periode akuntansi dan pada umumnya penjualan secara kredit biasanya dengan syarat pembayaran (2/10, n/30), seperti piutang yang timbul dari penjualan barang atau jasa secara kredit. Sedangkan piutang di luar dagang merupakan adanya transaksi di luar dagang yang mengakibatkan timbulnya tagihan pada masa yang akan datang kepada konsumen, seperti: piutang dividen, piutang bunga, piutang sewa.

\subsection{Kerugian Piutang Tak Tertagih}

Ahmed (2015:67) dalam buku teori akuntansi, menyatakan bahwa piutang usaha tak tertagih adalah kerugian pendapatan yang memerlukan, melalui ayat jurnal pencatatan yang tepat dalam akun, penurunan aktiva piutang usaha serta penurunan yang berkaitan dengan laba dan ekuitas pemegang saham. Kerugian pendapatan dan penurunan laba diakui dengan mencatat beban piutang ragu-ragu (atau beban piutang tak tertagih). Beban piutang tak tertagih merupakan biaya bagi penjual yang memberikan kredit.

\section{METODE PENELITIAN}

\subsection{Jenis Penelitian}

Penelitian ini menggunakan penelitiam deskriptif, yang bertujuan untuk memberikan gambaran mengenai keadaan perusahaan dengan melakukan kegiatan observasi dan wawancara. Menurut Sugiyono (2015:36), Penelitian Deskripsif adalah penelitian yang dimaksudkan menyelidiki keadaan, kondisi atau hal-hal lain yang sudah disebutkan yang hasilnya dipaparkan dalam bentuk laporan penelitian.

Penelitian yang digunakan adalah penelitian deskriptif kualitatif. Penelitian deskriptif adalah pendapat terhadap individu, organisasi, keadaan, ataupun prosedur atau penilaian sikap. Data deskriptif pada umumnya dikumpulkan melalui daftar pertanyaan dalam survei, wawancara, ataupun observasi. Metode Penelitian kualitatif adalah metode penelitian yang digunakan untuk meneliti pada kondisi objek yang alamiah, dimana peneliti adalah sebagai instrument kunci, pengumpulan data dilakukan secara trianulasi (gabungan), analaisis data bersifat induktif, dan hasil penelitian kualitiatif lebih menekankan makna dari pada generalisasi (Sugiyono, 2015:38). Penelitian dengan analisis data yang menggunakan metode deskriptif kualitatif yaitu metode penelitian dengan cara mengumpulkan data-data lalu akan dikelompokkan dan disusun agar dapat diteliti berdasarkan teori yang relevan serta berhubungan dengan masalah yang dibahas sehingga untuk kemudian dapat diambil atau ditarik suatu kesimpulan, dan peneliti juga menggunakan penelitian pada kondisi objek yang alamiah (Sugiyono, 2015) 


\subsection{Tempat Dan Waktu Penelitian}

Penelitian ini dilaksanakan pada PT. Bank Rakyat Indonesia Cabang Bitung, Dengan waktu penelitian dimulai pada bulan Februari 2018.

\subsection{Prosedur Penelitian}

Adapun langkah-langkah yang dilakukan dalam pelaksanaan penelitian pada PT. Bank Rakyat Indonesia Cabang Bitung sebagai berikut:

1. Peneliti membuat surat penelitian dibagian akademik fakultas ekonomi dan bisnis terus mengajukan permohonan untuk mengadakan penelitian melalui bagian kredit dan keuangan PT. Bank Rakyat Indonesia Cabang Bitung kemudian mengidentifikasi masalah mengenai judul skripsi yang akan diteliti kemudian memilih variabel yang sesuai dengan permasalahan didapat sesuai dengan data yang akan diteliti.

2. Peneliti menunggu surat penelitian disetujui kemudian melakukan proses pengambilan data berupa internal perusahaan berupa jurnal posting perusahaan, sejarah, bahkan struktur.

3. Peneliti melakukan wawancara bersama Pimpinan perusahaan PT. Bank Rakyat Indonesia Cabang Bitung, mengingat keterbatasan waktu dari pimpinan sehingga dipindahkan untuk menjadi objek wawancara yaitu kepala divisi kredit.

4. Peneliti menganalisis keseluruhan data-data mengenai laporan keuangan yang telah didapat dari PT. Bank Rakyat Indonesia Cabang Bitung yang menjadi objek penelitian dari peneliti maupun informasi yang didapat dari buku-buku, jurnal dan internet kemudian mengola seluruh data tersebut sesuai dengan teori yang dipelajari oleh peneliti.

5. Setelah pengumpulan data dan analisis data dilakukan maka peneliti membuat evaluasi penelitian sesuai dengan data yang didapat kemudian membuat kesimpulan dan saran untuk PT. Bank Rakyat Indonesia Cabang Bitung.

\subsection{Metode Pengumpulan Data}

Pada metode ini, peneliti harus menetukan terlebih dahulu sumber data, jenis data, dan teknik yang digunakan dalam pengumpulan data.

\subsubsection{Jenis Data}

Jenis Data yang dipakai :

1. Data Kualitatif

Data kualitatif adalah data yang berbentuk atau tersusun dari kata-kata.Data kualitatif diperoleh dengan mewawancarai, menganalisis dokumen, diskusi terfokus, atau observasi.

2. Data Kuantitatif

Data kuantitatif merupakan data yang berupa angka-angka yang diperoleh dari perhitungan data kualitatif yang menunjukkan hasil pengukuran variabel untuk keperluan penelitian.

\subsubsection{Sumber Data}

Ada dua sumber data dan metode pengumpulan data antara lain :

1. Data Primer

Data primer yaitu data yang dibuat untuk menyelesaikan permasalahan yang sedang ditanganinya. Data tersebut dikumpulkan peneliti langsung dari sumber atau tempat objek penelitian dilakukan. Data primer yang digunakan penulis adalah wawancara yang berupa tanya jawab langsung dengan pihak-pihak yang terkait.

2. Data Sekunder

Data sekunder merupakan sumber data penelitian yang didapat secara tidak langsung melalui media perantara. Data sekunder yang penulis kumpulkan dari pihak internal perusahaan antara lain: 
1. Sejarah perusahaan

2. Struktur organisasi

3. Laporan Keuangan (Pendapatan,Beban,liabilitas)

\subsubsection{Teknik Pengumpulan Data}

Teknik pengumpulan data merupakan cara pengumpulan data yang dibutuhkan untuk menjawab rumusan masalah penelitian. Teknik pengumpulan data dalam penelitian ini adalah:

1. Metode Wawancara

Melakukan tanya jawab dengan pihak perusahaan mengenai data-data yang diperlukan. Dokumentasi, meneliti setiap data-data yang diperoleh dari perusahaan melalui hasil wawancara. Dokumen merupakan catatan peristiwa yang sudah berlalu. Dokumen bisa berbentuk tulisan, gambar, atau karya-karya monumental dari seorang.

2. Metode Observasi

Observasi adalah metode pengumpulan data yang yang dilakukan dengan sengaja. Metode pengumpulan data ini digunakan untuk mengukur sikap dari responden, namun juga dapat digunakan untuk merekam situasi dan kondisi yang terjadi.

\subsection{Metode Analisis}

Penelitian ini merupakan penelitian yang bersifat deskriptif kualitatif dengan tujuan untuk memberikan gambaran yang mendetail tentang latar belakang, sifat-sifat serta karakteristik yang khas dari subjek penelitian. Analisis ini digunakan untuk membahas dan menerangkan hasil penelitian dengan menggunakan keterangan-keterangan yang tidak berbentuk angka. Dalam penelitian kualitatif, analisis data tidak harus menunggu selesainya pengumpulan data. Analisis data bersifat berkelanjutan dan dikembangkan sepanjang program (Sugiyono 2015:40-42).

\section{HASIL ANALISIS DAN PEMBAHASAN}

\subsection{Gambaran Umum Perusahaan}

Bank Rakyat Indonesia (BRI) adalah salah satu bank milik pemerintah didirikan di Purwokerto, Jawa Tengah pada tanggal 16 Desember 1895. Kegiatan BRI sempat terhenti sementara pada tahun 1948 dan beroperasi kembali pada tahun 1949.

Kegiatan Bank BRI didasarkan pada bisnis yang berfokus pada golongan masyarakat kecil, fokus ini masih konsisten sampai saat ini dimana Bank BRI bergerak dalam pemberian fasilitas kredit kepada golongan pengusaha kecil. Komitmen BRI ini berasal dari besarnya komposisi pinjaman yang diberikan atau disalurkan kepada pengusaha kecil, ritel dan menengah difokuskan atau ditujukan bagi Usaha Kecil dan Menengah (UKM).

\subsection{Hasil Penelitian}

Non Performing Loan (NPL) adalah kredit bermasalah yang merupakan salah satu kunci untuk menilai kualitas kinerja. Dalam laporan keuangan perbankan, NLP dibagi menjadi 2, yaitu NPL gross dan NPL net. Kategori kurang lancar, diragukan dan macet (dijumlah semua) dengan total kredit adalah kategori dalam NPL gross. Sedangkan NPL net yaitu perbandingan antara kredit macet dean total kredit. Berikut adalah rumus NPL :

$$
\mathrm{NPL}=\frac{\text { Kredit Macet (Kredit Kurang Lancar + Diragukan }+ \text { Macet })}{\text { Total Kredit }}
$$

Semakin tinggi NPL, maka semakin besar kredit macet perbankan (semakin jelek kualitas bank tersebut). Semakin besar NPL, juga akan sangat berpengaruh buruk pada kinerja keuangan perbankan. NPL bisa naik dan turun, NPL yang bagus adalah NPL yang menurun. NPL yang rendah menunjukan bahwa bank mampu mencari calon debitur yang berkualitas.

PT. Bank Rakyat Indonesia Cabang Bitung memiliki jumlah piutang sebesar Rp1 16.484.410.609 dengan NPL sebesar 2.77\% dan itu masuk dalam kategori pengendalian 
piutang yang baik. Pada tahun 2014 PT. Bank Rakyat Indonesia Cabang Bitung memiliki jumlah piutang sebesar Rp112.738.178.085 dengan NPL sebesar 1.71\% yang merupakan penurunan yang jauh dari tahun 2013 dan itu menunjukan hasil yang baik bagi pengelolaan piutang pada PT. Bank Rakyat Indonesia Cabang Bitung. Pada tahun 2015 PT. Bank Rakyat Indonesia Cabang Bitung memiliki jumlah piutang sebesar Rp135.634.640.731 dengan NPL sebesar $1.49 \%$ merupakan penurunan dari tahun 2014 walaupun tidak jauh dibandingkan dengan tahun 2013 ke 2014 tapi ini merupkan hasil yang baik karena grafikmya menurun. Pada tahun 2016 PT. Bank Rakyat Indonesia Cabang Bitung memiliki jumlah piutang sebesar Rp187.941.884.039 dengan NPL sebesar 1.31\% merupakan penurunan dibandingkan dengan tahun 2015 yang meneruskan hasil yang baik dengan grafik yang menurun. Dan pada tahun 2017 PT. Bank Rakyat Indonesia Cabang Bitung memiliki jumlah piutang sebesar Rp268.965.965.374 dengan NPL sebesar 1.58\% walaupun grafiknya naik dari tahun 2016 tapi pengelolaan piutang ditahun 2017 masih jauh dari kategori tidak baik.

\subsection{Pengelolaan Piutang Pada PT. Bank Rakyat Indonesia Cabang Bitung}

Semakin lama umur piutang maka semakin besar juga persentase kerugian sementara yang akan di tanggung perusahaan dan kemungkinan akan tidak tertagihnya juga semakin besar. Oleh karena itu, diperlukan perhatian khusus terhadap piutang yang menurut perusahaan kurang aman dan tidak aman, karena dapat meningkatnya risiko akan tidak tertagihnya piutang tersebut dan akan merujuk pada kebangkrutan.

Menurut Standar Akuntansi Kuangan (IAI, 1995: PSAK No. 9), istilah piutang tak tertagih disebut "Cadangan Kerugian Piutang", tetapi untuk PT. Bank Rakyat Indonesia Cabang Bitung menggunakan istilah "Cadangan Aktiva Produktif". Dengan adanya Cadangan Aktiva Produktif, maka jumlah piutang tak tertagih akan berbanding lurus sesuai dengan persentase penjualan kredit pada tahun berjalan.

Cadangan Aktiva Produktif adalah dana cadangan perusahaan untuk mengganti jika terjadi piutang tak tertagih, Cadangan Aktiva Produktif bertujuan untuk mengukur kualitas kredit yang diberikan kepada nasabah. Jika nasabah tidak dapat melunasi piutang yang tidak tertagih maka secara otomatis perusahaan akan menutupi piutang tersebut dengan dana yang telah disediakan perusahaan (cadangan aktiva produktif) dan mengakibatkan perusahaan mengalami kerugian yang bersifat sementara. Dan apabila nasabah telah melunasi atau membayar angsuran, maka secara otomatis sistem akan mengembalikan kerugian perusahaan yang sementara itu.

Perusahaan menetapkan piutang yang berumur <30 hari sebagai piutang dalam kategori lancar, hal ini dikarenakan perusahaan mempunyai kebijakan dalam penagihan piutang yang telah tepat waktu. Dan untuk piutang yang berumur 31-60 hari dalam kategori tidak aman dan memerlukan perhatian khusus untuk diberi kelonggaran waktu dalam batas tertentu. Sedangkan untuk piutang yang berumur 91-120 hari dalam kategori kurang lancar, begitu juga dengan piutang yang berumur 121-180 hari dalam kategori diragukan. Dan untuk piutang berumur $>180$ hari dalam kategori macet. Sedapat mungkin bagian penagih tetap melakukan penagihan terhadap pelanggan dalam kategori tersebut.

Penggolongan piutang pada PT. Bank Rakyat Indonesia Cabang Bitung dilakukan dengan tujuan untuk memudahkan pelaksanaan pencatatan atas transaksi yang mempengaruhi piutang yang ada. Untuk tujuan pelaporan keuangan, PT. Bank Rakyat Indonesia menggolongkan piutang menurut lamanya tanggal jatuh tempo. Penggolongan seperti ini menghasilkan piutang lancar atau piutang jangka pendek dan piutang tidak lancar atau piutang jangka panjang.

BI menempatkan risiko kredit dimaksud pada urutan pertama pada PBI No.15/2/PBI/2013, Bab VIII, Pasal 36, Ayat 1b. Risiko kredit pada PT. Bank Rakyat Indonesia Cabang Bitung ditinjau dengan menggunakan rasio NPL yang dibatasi dengan standar BI maksimal 5\%. Kebijakan PT. Bank Rakyat Indonesia Cabang Bitung dalam 
melakukan pengendalian piutang yaitu dengan mengestimasi piutang bermasalah sebesar $3 \%$. Apabila piutang tak tertagih $<3 \%$, maka pengendalian piutangnya baik. Tetapi jika piutang tak tertagih $>3 \%$, maka pengendalian piutangnya tidak baik. Dari metode pengedalian piutang tersebut, maka dapat diketahui bahwa jumlah piutang tak tertagih pada PT. Bank Rakyat Indonesia Cabang Bitung masih berada <3\%, sehingga disimpulkan bahwa pengendalian piutang PT. Bank Rakyat Indonesia Cabang Bitung telah berjalan dengan baik.

\section{KESIMPULAN DAN SARAN}

\subsection{Kesimpulan}

Berdasarkan penelitian dan pembahasan yang telah dikemukan pada bab IV, dapat ditarik kesimpulan bahwa :

1. Berdasarkan tabel 4.3.1 pengelolaan piutang pada PT. Bank Rakyat Indonesia Cabang Bitung telah berjalan dengan baik berdasarkan Lingkungan Pengendalian, Penentuan Resiko, Aktivitas Pengendalian, Informasi Komunikasi dan Pengawasan Dan Pemantauan.

2. Pengelolaan piutang tak tertagih pada PT. Bank Rakyat Indonesia Cabang Bitung menggunakan metode cadangan atau penyisihan berdasarkan kategori umur piutang. Semakin lama umur piutang maka semakin besar juga persentase kerugian sementara yang akan ditanggung oleh perusahaan dan kemungkinan akan tidak tertagihnya juga semakin besar. PT. Bank Rakyat Indonesia Cabang Bitung mengestimasi piutang bermasalah sebesar 3\%. Apabila piutang tak tertagih $<3 \%$, maka pengelolaan piutangnya baik. PT. Bank Rakyat Indonesia Cabang Bitung menggolongkan piutang menurut lamanya tanggal jatuh tempo. Penggolongan semacam ini akan menghasilkan piutang lancar atau piutang jangka pendek dan piutang tidak lancar atau piutang jangka panjang.

\subsection{Saran}

Dengan adanya kesimpulan di atas, setelah melakukan analisis dan evaluasi, maka ada beberapa hal yang perlu mendapat perhatian dan hendaknya diadakan perbaikan-perbaikan yang membutuhkan pertimbangan untuk melaksanakannya. Untu $\mathrm{k}$ itu, penulis mengemukakan beberapa saran yang diharapkan dapat membantu pihak perusahaan dalam mengatasi masalah penanganan piutang perusahaan dan sekaligus menjadi bahan tindakan preventif yang dapat dilakukan pada masa yang akan datang. Adapun saran-saran tersebut adalah sebagai berikut:

1. Dalam melakukan survei dan analisa kepada calon debitur, surveyor harus lebih memperhatikan kondisi calon debitur tersebut apakah memenuhi persyaratan atau tidak sehingga layak untuk dilakukan pembiayaan dengan lebih memperhatikan aspek 5C serta wajib menjelaskan mengenai paham kredit kepada calon debitur. Diharapkan dengan debitur yang berkualitas, maka jumlah bad customer dan piutang tak tertagih menjadi semakin kecil dan pengelolaan piutang pada PT. Bank Rakyat Indonesia Cabang Bitung diharapkan menjadi lebih baik.

2. Sebaiknya pihak PT. Bank Rakyat Indonesia Cabang Bitung semaksimal mungkin menekan timbulnya piutang. Misalnya dengan melaksanakan pengelolaan piutang secara efektif atau memperketat sistem pengawasan terhadap piutang. Sebaiknya pihak PT. Bank Rakyat Indonesia Cabang Bitung lebih teliti lagi dalam mengevaluasi kondisi keuangan nasabah dan 


\section{DAFTAR PUSTAKA}

Ahmed Riahi Belkaoui. 2015. Teori Akuntansi. Buku 1. Edisi 5. Penerbit Salemba Empat. Jakarta.

Committee of Sponsoring Organization of the Treadway Commission (COSO). 2013.

Dacosta Imanuella. 2015. Analisis Kerugian Piutang Tak Tertagih Pada PT.Metta Karunia Jaya Makassar. Jurnal EMBA. Vol 3. No. 1 Diakses tanggal 26 November 2017. Hal.695-706.

Erdi Kuriawan Syaputera. 2013. Analisis Piutang Tak Tertagih Pada PT. Bima Finance Palembang. Jurnal Nasional.

Hery. 2013. Teori Akuntansi. Lembaga FE-UI. Jakarta.

Ikatan Akuntansi Indonesia. 1995. Standar Akuntansi Indonesia. Jakarta: Salemba Empat.

Kasmir. 2015. Bank dan Lembaga Keuangan Lainnya. Jakarta. PT. Raja Grafindo Persada.

Milda Veralita. 2014. Faktor-Faktor Mempengaruhi Penyebab Piutang Tak Tertagih Pada

Koperasi Baitul Malwat Tamwil Palembang. Jurnal Nasional. Diakses 8 Mei 2017.

Mulyadi. 2016. Sistem Akuntansi. Edisi Empat. Jakarta: Salemba Empat.

Reeve, Warren, Duchac. 2015. Accounting : Pengantar Akuntansi, Terjemahan Aria Farahmita, Amanugrahani, dan Taufik Hendrawan, Edisi 21, Buku 2, Salemba Empat, Jakarta.

Sugiyono. 2015. Metode Penelitian Bisnis. Cetakan ke-15.Alfabeta. Bandung.

Sunyoto D. 2013. Metodologi Penelitian Akuntansi. Cetakan Satu. Penerbit Refika Aditama. Bandung.

Supraptomo. 2013. Analisis Pemeriksaan Operasional Untuk Menilai Efesiensi Dan Efektivitas Atas Penjualan Dan Piutang Usaha. Jurnal Akuntansi \& Keuangan. Vol.2 No.2. Diakses 7 Mei 2017.

Suwarno. 2013. Analisis Sistem Pengendalian Internal Atas Piutang Untuk Meminimalkan Jumlah Piutang Tak Tertagih Pada PT. Olympindo Multifinance. Jurnal Nasional. Diakses 10 Agustus 2017.

Syakur Syafi'i Ahmad. 2015. Intermediate Accounting, AV Publisher, Jakarta.

Tuanakotta, Theodorus. M, 2015. Audit Kontemporer. Jakarta: Salemba Empat.

Wild dan Kwok. 2011. Accounting and Financial Accounting. Buku Financial Accounting. 